\title{
Growth and Physiological Traits Associated with Drought Survival and Post-drought Recovery in Perennial Turfgrass Species
}

\author{
Qi Chai \\ Key Laboratory of Grassland Agro-Ecosystem Ministry of Agriculture, College of Pastoral \\ Agricultural Science and Technology, Lanzhou University, Lanzhou, 730020, The People's Republic \\ of China; and Department of Biology and Pathology, Rutgers, The State University of New Jersey, \\ New Brunswick, NJ 08901
}
Fang Jin
Department of Biology and Pathology, Rutgers, The State University of New Jersey, New Brunswick, NJ 08901; and College of Agronomy, Gansu Agricultural University, Lanzhou 730070, People's Republic of China

\begin{abstract}
Emily Merewitz and Bingru Huang ${ }^{1}$
Department of Biology and Pathology, Rutgers, The State University of New Jersey, New Brunswick, NJ 08901
\end{abstract}

\begin{abstract}
AdDitional INDEX wORDs. kentucky bluegrass, osmotic adjustment, perennial ryegrass, cell wall elasticity, electrolyte leakage

Aвstract. The objective of this study was to determine physiological traits for drought survival and post-drought recovery upon re-watering in two $\mathrm{C}_{3}$ perennial grass species, kentucky bluegrass [KBG (Poa pratensis)] and perennial ryegrass [PRG (Lolium perenne)]. Plants were maintained well watered or exposed to drought stress by withholding irrigation and were then re-watered in a growth chamber. KBG had significantly higher grass quality and leaf photochemical efficiency, and lower electrolyte leakage than PRG during 20 days of drought. After 7 days of rewatering, drought-damaged leaves were rehydrated to the control level in KBG, but could not fully recover in PRG. KBG produced a greater number of new roots, while PRG had more rapid elongation of new roots after 16 days of rewatering. Superior drought tolerance in KBG was associated with osmotic adjustment, higher cell wall elasticity, and lower relative water content at zero turgor. Osmotic adjustment, cell wall elasticity, and cell membrane stability could play important roles in leaf desiccation tolerance and drought survival in perennial grass species. In addition, postdrought recovery of leaf hydration level and physiological activity could be associated with the accumulation of carbohydrates in leaves and rhizomes during drought stress and new root production after re-watering.
\end{abstract}

Water availability for agricultural or urban irrigation is becoming increasingly limited, which is a common threat for plant growth in many areas. The mechanisms of drought tolerance in terms of plant productivity under moderate drought have been investigated extensively in many crop species, but mechanisms contributing to desiccation tolerance or drought survival in perennial grasses have received limited attention (Volaire and Lelievre, 2001). Improving the persistence and survivability of perennial species is critically important in areas with prolonged periods of drought. In addition, rapid recovery of damaged plant tissue and re-growth of new tissue following drought stress when water becomes available are also important in perennial grass management to ensure rapid stand reestablishment. Post-drought recovery is largely dependent on the recovery of existing leaf tissue and the regeneration of new tissue from crowns, stolons, and rhizomes of grass plants.

Received for publication 4 Feb. 2010. Accepted for publication 25 Mar. 2010. We wish to express thanks to the Chinese Scholarship Council and Rutgers Center of Turfgrass Science for supporting the research. Thanks also go to Dr. Chenping Xu, David Jespersen, and Yan Xu for critical review of the manuscript.

${ }^{1}$ Corresponding author. E-mail: huang@aesop.rutgers.edu.
Plant response to drought stress involves changes in various morphological and physiological factors (Nilsen and Orcutt, 1996; Shinozaki and Yamaguchi-Shinozaki, 1997). Leaf dehydration tolerance has been attributed to at least two mechanisms: osmotic adjustment (involving inorganic ions, carbohydrates, and organic acids), and changes in cellular/ tissue elasticity [i.e., bulk elastic modulus $(\varepsilon)$ ] (Touchette, 2006). Osmotic adjustment and high cell wall elasticity can modify the relationship between turgor pressure and cell volume, facilitating the maintenance of cell turgor and cell growth under drought stress (Blake et al., 1991; Saito and Terashima, 2004). Continuing leaf expansion and maintaining turgid leaves under drought stress are highly desirable traits for improving crop production during drought stress and rapid recovery from drought damages upon rewatering (Siopongco et al., 2006).

Drought tolerance and recuperative potential vary with grass species (Carrow, 1996; DaCosta and Huang, 2006; Su et al., 2008; Volaire and Gandoin, 1996). Kentucky bluegrass (KBG) and perennial ryegrass (PRG) are $\mathrm{C}_{3}$ perennial species widely used as turfgrass in cool climatic regions (Beard, 1973; Sun, 2008). It is generally believed that KBG has better drought tolerance than PRG, and some researchers have attributed the 
difference to greater rhizome production in $\mathrm{KBG}$, which would serve as carbohydrate storage organs during stress (Beard, 1973; Ensign and Weiser, 1975; Fry and Huang, 2004; Turgeon, 1996). Carbohydrate accumulation in grass crown or rhizomes is important for the regeneration of new shoots and roots (DaCosta and Huang, 2006; Volaire and Gandoin, 1996). For re-growth and re-hydration of existing leaves from drought damage, physiological factors controlling cellular hydration and cell integrity may play critical roles. The maintenance of cellular hydration and membrane integrity of leaves could contribute to better recuperative ability in KBG (Ma and Wang, 2001; Sun et al., 2001) and other cool-season grass species (DaCosta and Huang, 2006). However, major physiological factors underlying the ability of re-growth and rehydration of drought-damaged leaves in perennial grass species are largely unknown. Understanding physiological factors that enable perennial grasses to survive and grow during periods of limited soil moisture and to rapidly recover from drought damage upon re-watering or rainfall events is important in grass management, particularly in water-limiting environments.

The objective of this study was to determine the major physiological traits associated with leaf desiccation tolerance and post-drought recuperative ability by comparing physiological responses to drought stress and re-watering between KBG and PRG differing in drought tolerance. Correlation analysis among $\psi_{\mathrm{S}}$ at full turgor, cell wall elasticity, critical water hydration level, cell membrane stability, and grass quality was performed to determine relationships between these traits associated with drought survival. In addition, the production of new tillers and new roots during re-watering was evaluated to determine recuperative potential.

\section{Materials and Methods}

Plant materials and growth conditions. 'Midnight' KBG and 'Paragon GLR' PRG were examined. These cultivars of KBG and PRG were selected because both were reported to have good grass quality and drought resistance within the species (Hardebeck and Bigelow, 2008; Wang and Huang, 2004). Mature sods of KBG and PRG were collected from Rutgers University research farm, North Brunswick, NJ, and were planted in plastic containers $(60 \mathrm{~cm}$ deep and $10 \mathrm{~cm}$ in diameter) filled with a mixture $(1: 1 \mathrm{v} / \mathrm{v})$ of fine sand and silt loam soil (fine, montmorillonitic, mesic, Aquic, Arquidoll) that was sterilized before planting. Plants were maintained in a greenhouse for $40 \mathrm{~d}$ under 12 to $14 \mathrm{~h}$ natural light conditions with average level of photosynthetically active radiation $(P A R)$ at $760 \mu \mathrm{mol} \cdot \mathrm{m}^{-2} \cdot \mathrm{s}^{-1}$ and temperatures of $\approx 23 / 17^{\circ} \mathrm{C}$ (day/night), and were then moved to a walk-in growth chamber where treatments were imposed. The growth chamber $(3 \times 2.5 \mathrm{~m})$ was set at $23 / 18{ }^{\circ} \mathrm{C}$ (day/night), $60 \%$ relative humidity, and a 12 -h photoperiod with $P A R$ of 550 $\mu \mathrm{mol} \cdot \mathrm{m}^{-2} \cdot \mathrm{s}^{-1}$ at the canopy level. Before drought stress treatment, plants in each container were watered three times per week to maintain soil moisture at field capacity and were fertilized biweekly with $100 \mathrm{~mL}$ of $20 \mathrm{~N}-8.8 \mathrm{P}-16.6 \mathrm{~K}$ soluble fertilizer (Peter's General Purpose 20-20-20; Grace-Sierra, Milpitas, CA), including micronutrients at a concentration of $5 \mathrm{~g} \cdot \mathrm{L}^{-1}$ in $100 \mathrm{~mL}$ of the soluble fertilizer $(0.05 \% \mathrm{Mg}, 0.0068 \% \mathrm{~B}, 0.0036 \% \mathrm{Cu}$, $0.05 \% \mathrm{Fe}, 0.025 \% \mathrm{Mn}, 0.0009 \% \mathrm{Mn}$, and $0.0025 \% \mathrm{Zn})$. The grass was hand-clipped weekly to maintain a height $\approx 6$ to $8 \mathrm{~cm}$.

Treatment AND EXPERIMENTAL DESIGN. After a 14-d acclimation to growth chamber conditions, plants were exposed to three treatments: 1) in the well-watered control treatment, plants were watered three times per week until water drained from the bottom of the container at each irrigation; 2) in the drought stress treatment, irrigation was withheld until permanent leaf wilting occurred; 3) in the re-watering treatment, plants were initially exposed to drought stress by withholding irrigation until complete desiccation of grass canopy, but then were irrigated every $2 \mathrm{~d}$ days to allow for recovery from drought stress.

Treatments and species were arranged as a completely randomized design with two factors (watering treatments and species). Each treatment for each species was repeated in four replicates (four pots).

SOIL WATER STATUS AND PHYSIOlOgical RESPONSES TO DROUGHT AND RE-WATERING. Soil volumetric water content (SWC) in a 0 - to $20-\mathrm{cm}$ deep soil layer of each container was measured as an indication of the level of soil water deficit using time domain reflectometry (Soil Moisture Equipment, Santa Barbara, CA) by inserting the 20 -cm-long wave guide vertically in the top $20 \mathrm{~cm}$ soil profile.

Grass quality (GQ), leaf relative water content (RWC), leaf cell membrane stability [electrolyte leakage (EL)], leaf chlorophyll content $(\mathrm{Chl})$, and leaf photochemical efficiency $(\mathrm{Fv} /$ Fm) were measured at $0,5,10,15$, and $20 \mathrm{~d}$ of drought stress and 3 and $7 \mathrm{~d}$ of re-watering. During 3 and $7 \mathrm{~d}$ of re-watering, these measurements were taken only on existing leaves that were previously exposed to drought stress to examine the recovery potential of stressed tissues.

Grass quality was rated based on a leaf color and turgidity level, which is a nondestructive parameter and the most widely used one in the evaluation of the overall performance and growth of a grass stand and survivability of perennial grass plants under stressful conditions (Beard, 1973; Turgeon, 1996). It was visually rated on a scale from 0 to 9 , where the grass quality was rated as zero if leaves were completely brown and desiccated and rated as 9 when leaves were green and fully hydrated.

Leaf water status was determined by measuring RWC calculated as follows: RWC $(\%)=100 \times(\mathrm{FW}-\mathrm{DW}) /(\mathrm{TW}-$ $\mathrm{DW})$, where FW is the leaf fresh weight, DW is leaf dry weight for tissues dried at $85{ }^{\circ} \mathrm{C}$ for $3 \mathrm{~d}$, and TW is turgid weight of leaves after being soaked in water for $4 \mathrm{~h}$ at $\approx 20^{\circ} \mathrm{C}$ (Barrs and Weatherley, 1962).

Cell membrane stability was estimated by calculating the percentage EL from leaf cells. About 10 first and second fully expanded leaves per container were excised and cut into $2-\mathrm{cm}-$ long pieces. They were rinsed three times in distilled water and placed into vials containing $20 \mathrm{~mL}$ of distilled water. After shaking for $6 \mathrm{~h}$, initial conductivity $\left(\mathrm{C}_{\mathrm{i}}\right)$ of the bathing solution containing fresh leaves was measured with a conductivity meter (YSI, Yellow Spring, OH). Leaves were then killed in an autoclave at $140{ }^{\circ} \mathrm{C}$ for $30 \mathrm{~min}$ and were placed on a shaker for $24 \mathrm{~h}$ before maximum conductivity $\left(\mathrm{C}_{\max }\right)$ of the bathing solution was measured. The EL was calculated as $100 \times \mathrm{C}_{\mathrm{i}}$ / $\mathrm{C}_{\max }$ (DaCosta et al., 2004).

Leaf photochemical efficiency expressed as the ratio of variable to maximum chlorophyll fluorescence (Fv/Fm ratio) was determined on five individual leaves in each container with a fluorescence induction monitor (Fim 1500; ADC Bioscientific, Hodderston, UK) after dark adaptation for $30 \mathrm{~min}$. Leaf Chl content was extracted by soaking 0.05 to $0.1 \mathrm{~g}$ leaves in $10 \mathrm{~mL}$ of dimethyl sulfoxide in the dark for $72 \mathrm{~h}$ (Hiscox and 
Israeltem, 1979). Absorbance of extracted Chl was measured at 663 and $645 \mathrm{~nm}$ using a spectrophotometer (Genesys 2; Spectronic Instruments, Rochester, NY) (Jiang and Huang, 2001).

The content of total nonstructural carbohydrate (TNC) in leaves of both species, crowns in PRG and rhizomes in $\mathrm{KBG}$, was analyzed following the method described in Nelson (1944) and Somogyi (1945), with some modifications. After plants were washed free of soil, leaves, crowns, or rhizomes were immediately frozen in liquid nitrogen, and then stored at $-80{ }^{\circ} \mathrm{C}$. Before analysis, samples were dried in a freeze-drier (Labconco, KS City, MO). Samples were grounded with a mortar and pestle and passed through a $0.35-\mathrm{mm}$ screen. A 40-mg ground sample was hydrolyzed with $2.5 \mathrm{~mL}$ of amylase for $24 \mathrm{~h}$ at $37^{\circ} \mathrm{C}$ and then $0.5 \mathrm{~mL}$ of $0.6 \mathrm{~N} \mathrm{HCl}(1: 1 \mathrm{v} / \mathrm{v})$ was added for tissue digestion for another $18 \mathrm{~h}$. After the solution $\mathrm{pH}$ was adjusted between 5 and 7 with $0.31 \mathrm{~mL}$ of $10 \mathrm{~N} \mathrm{NaOH}$, the solution was transferred into a flask and the volume was brought to $50 \mathrm{~mL}$ with distilled water. A $1.0-\mathrm{mL}$ aliquot of filtered solution was transferred into a graduated test tube containing $1.5 \mathrm{~mL}$ of alkaline ferricyanide solution. The mixture was heated in a boiling water bath for $10 \mathrm{~min}$ and was then quickly cooled in water or in an ice bath. The $\mathrm{pH}$ was partially neutralized with $3.0 \mathrm{~mL}$ of $2 \mathrm{~N} \mathrm{H}_{2} \mathrm{SO}_{4}$. The solution was shaken vigorously until no more gas was released from the solution. Finally, $1.2 \mathrm{~mL}$ of arsenomolybdate solution was added to develop green color and the volume was brought up to total of $25 \mathrm{~mL}$ with distilled water. The absorbance of the solution was measured at $515 \mathrm{~nm}$ using a spectrophotometer (Genesys 2) and the amount of sugar was determined by reference to a standard curve.

Construction of Pressure-volume Curve for the ESTIMATE OF CELL WALL ELASTICITY, $\psi_{\text {S AT FULL TURGOR, AND }}$ RELATIVE WATER CONTENT AT ZERO TURGOR. A pressure-volume technique is widely used to study water relations of plants, providing estimation of $\psi_{\mathrm{S}}$ at full turgor and critical tissue water content during plasmolysis, as well as cell wall elasticity (Barker et al., 1993; Kirkham, 2005; Schulte and Hinckley, 1985; White et al., 1992; Wilson et al., 1979). A total of 30 fully extended leaves were detached from plants in each container and used for the development of the pressure-volume curve for plants exposed to well-watered conditions and $15 \mathrm{~d}$ of drought stress when leaf lamina of all plants were completely wilted. The pressure-volume curve was developed for each species by plotting the reciprocal of leaf water potential $(1 / \psi)$ against RWC following the methods described by White et al. (1992) and Barker et al. (1993). Leaves were detached from the plant and were rehydrated in distilled water in the dark at $4{ }^{\circ} \mathrm{C}$ for $16 \mathrm{~h}$ until fully turgidity or a constant weight was reached. Individual leaves were then subjected to the following procedure: 1) they were blotted dry for the determination of turgid weight (TW); 2) they were kept in petri dishes in a growth chamber with a constant temperature of $23{ }^{\circ} \mathrm{C}$, a $P A R$ of 500 $\mu \mathrm{mol} \cdot \mathrm{m}^{-2} \cdot \mathrm{s}^{-1}$, and a relative humidity of $70 \%$; 3) they were weighed for leaf FW every $5 \mathrm{~min}$; 4) immediately after FW measurement, leaf $\psi$ was measured using a pressure chamber (Soil Moisture Equipment) following the method described by Kirkham (2005); and 5) after leaf $\psi$ measurement, the leaf was dried in an oven at $80{ }^{\circ} \mathrm{C}$ for $48 \mathrm{~h}$ and DW was determined.

Leaf $\psi_{\mathrm{S}}$ at full turgor $\left(\psi_{\pi 100}\right)$ and relative water content at zero turgor $\left(\mathrm{RWC}_{0}\right)$ or incipient plasmolysis were derived from each pressure-volume curve (Wilson et al., 1979). Bulk modulus of elasticity of the leaf tissue $(\varepsilon)$ was determined from the relationship between pressure potential $\left(\psi_{\pi}\right)$ and RWC by assuming an approximate linear relation (Kirkham, 2005) by $\varepsilon=\left[\psi_{\mathrm{P}} / \mathrm{RWC}\right] \times \mathrm{RWC}_{0}$.

Turgid weight to dry weight ratio was determined from the turgid weight after full hydration and the dry weight of the leaf. TD/DW ratio indicates the extent of leaf cells to absorb water or cell wall hydration level (Malinowski and Belesky, 2000).

Production AND Growth of LEAVES, TILlers, AND ROOTS IN RESPONSE TO RE-WATERING. At 3 and $7 \mathrm{~d}$ of re-watering, the number of wilted, brown leaves and turgid, green leaves was counted to calculate the percentage of live leaves. Green leaves were separated from brown leaves and leaf area for each group was measured using the digimizer program (version 3.1.2.0; MedCalc Software, Mariakerke, Belgium). The percentage of green leaves to total leaf area was calculated.

At 7 and $16 \mathrm{~d}$ of re-watering, roots were washed free of soil and newly regenerated roots were separated from old, existing roots that were exposed to drought stress. Images of the new roots were scanned and analyzed for root number, length, and surface areas using WinRHIZO (Regent Instruments, Loretteville, Canada). Roots were then dried in an oven at $80{ }^{\circ} \mathrm{C}$ for $72 \mathrm{~h}$ to determine dry weight.

At the end of drought stress ( $20 \mathrm{~d})$, all shoots were removed at the shoot base in the re-watering treatment (Treatment 3 ). Plants were re-watered to examine the regeneration of new tillers in response to re-watering. At $16 \mathrm{~d}$ after rewatering, the number of new tillers was counted. The survival rate of plants was calculated as percentage of the number of new tillers to the total number of tillers.

Statistical analysis. The experiment was a completely randomized plot design with two factors (watering treatments and grass species). Treatment effects, species differences, and treatment $\times$ species interactions were determined by analysis of variance according to the general linear model procedure of SAS (version 9.0; SAS Institute, Cary, NC). Means were tested with least significant difference test at a probability level of 0.05 . Correlation analysis between physiological parameters was performed using a correlation matrices procedure with STATISTICA Software (StatSoft, Tulsa, OK).

\section{Results and Discussion}

SoIl WATER STATUS DURING DROUGHT AND RE-WATERING. Soil water content was measured as an indication of soil water status and it also provides a good estimate of the water depletion rate of a plant (Kirkham, 2005). SWC in a 20-cm soil depth in KBG and PRG declined rapidly as irrigation was withheld, to $4 \%$ by $20 \mathrm{~d}$ of drought stress in both species (Fig. 1). SWC increased to the pre-stress control level upon re-watering. No significant difference in SWC was found between the two species during the 20-d drying period or re-watering. This indicates that both species were exposed to the same level of water deficit or availability under drought stress and during re-watering, and the water depletion rate was not different between the two species. Therefore, the variation in growth performance and physiological responses to drought stress between KBG and PRG may not be associated with differences in soil water use rate.

Growth AND PHYSIOLOGICAL CHANGES AND CULTIVAR VARIATION IN DROUGHT TOLERANCE AND RECOVERY OF DROUGHT DAMAGES LEAVES. Grass quality of KBG and PRG declined with 


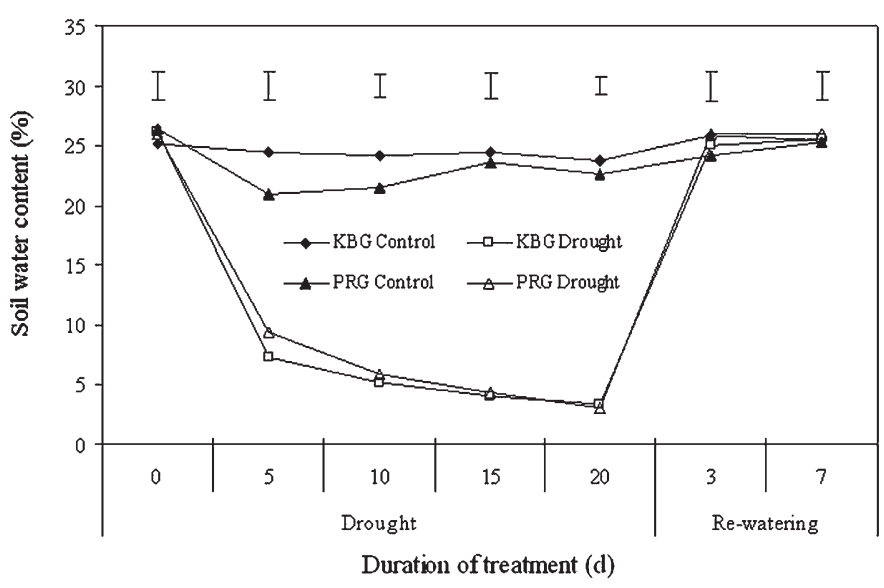

Fig. 1. Soil water content in 0 to $20 \mathrm{~cm}$ soil depth of kentucky bluegrass (KBG) and perennial ryegrass $(\mathrm{PRG})$ under drought stress and re-watering treatment Vertical bars on the top indicate LSD values $(P \leq 0.05)$ for species and treatments comparison at the given day of treatment.

drought stress and increased upon re-watering, but the extent of change varied between the two species (Fig. 2). Grass quality for KBG decreased to $40.3 \%$ of the well-watered control at $20 \mathrm{~d}$ of drought stress and then increased to $53.7 \%$ and $64.8 \%$ of the well-watered control at 3 and $7 \mathrm{~d}$ of re-watering, respectively. Grass quality for PRG decreased to $31.9 \%$ of the well-watered control at $20 \mathrm{~d}$ of drought stress and then increased to $35.2 \%$ and $46.3 \%$ of the well-watered control at 3 and $7 \mathrm{~d}$ of re-watering, respectively. Grass quality of KBG was $26.1 \%, 52.6 \%$, and $40.0 \%$ higher than that of PRG at $20 \mathrm{~d}$ of drought stress, 3 and $7 \mathrm{~d}$ of re-watering, respectively. The significantly higher grass quality and slower decline under drought and significantly more rapid and greater extent of recovery upon rewatering for KBG suggest that KBG had superior drought tolerance and better recuperative potential from drought damage compared with PRG. Ma and Wang (2001) also reported that after $20 \mathrm{~d}$ of drought stress, plants of three PRG genotypes were completely desiccated and died while five KBG genotypes still had an average survival rate of $58.4 \%$. Kanapeckas et al. (2008) also reported faster recovery of grass quality in KBG than PRG after $10 \mathrm{~d}$ re-watering. The interspecific difference in overall grass performance under drought stress and recuperative potential could be related to some of the physiological traits examined in this study, as discussed below.

Cell membrane stability (expressed as EL) has been widely used as an indicator of leaf desiccation tolerance (Martin et al., 1987). The level of cell damage increases with the plasma membrane permeability ( $\mathrm{Li}$ et al., 1994, 2004; Lu and Gao, 1996). Leaf EL for KBG increased significantly above the wellwatered control level at $15 \mathrm{~d}$ of drought, which was 7.0 times the well-watered control by $20 \mathrm{~d}$ of drought stress (Fig. 3). For PRG, significant increases in EL were found at $5 \mathrm{~d}$ of drought stress; by $20 \mathrm{~d}$ of drought, it increased to 8.0 times of the wellwatered control. EL of both species decreased at 3 and $7 \mathrm{~d}$ of rewatering compared with the level at $20 \mathrm{~d}$ of drought, but were still significantly higher than the respective well-watered controls. KBG leaves had significantly lower EL than PRG leaves during drought and re-watering. The EL data suggest that leaves of KBG and PRG experienced permanent cellular membrane damages when leaf RWC declined to $\approx 25 \%$ and

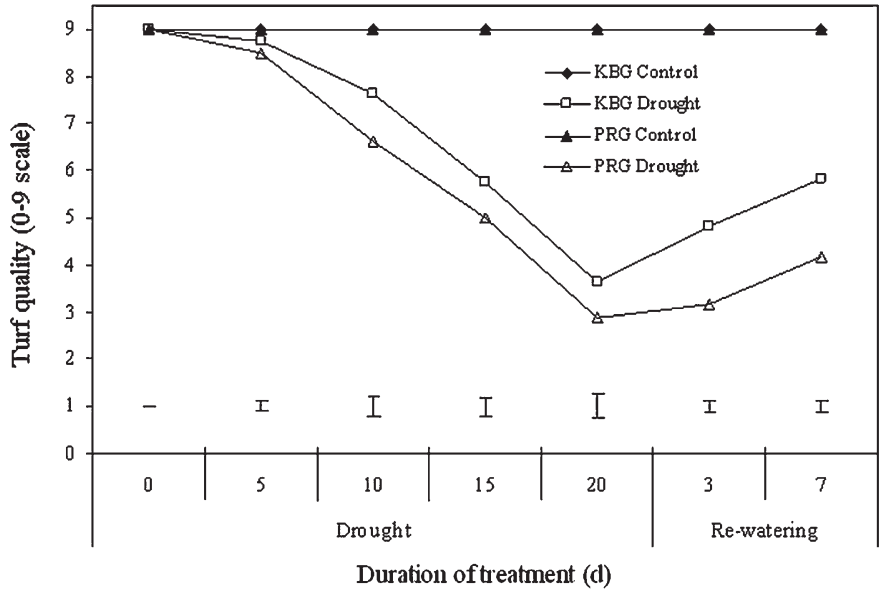

Fig. 2. Changes in turf quality for kentucky bluegrass (KBG) and perennial ryegrass (PRG) under drought stress and re-watering treatment. Turf quality was visually rated on the scale of 0 to 9 , with 9 being the best. Vertical bars on the top indicate LSD values $(P \leq 0.05)$ for species and treatments comparison at the given day of treatment.

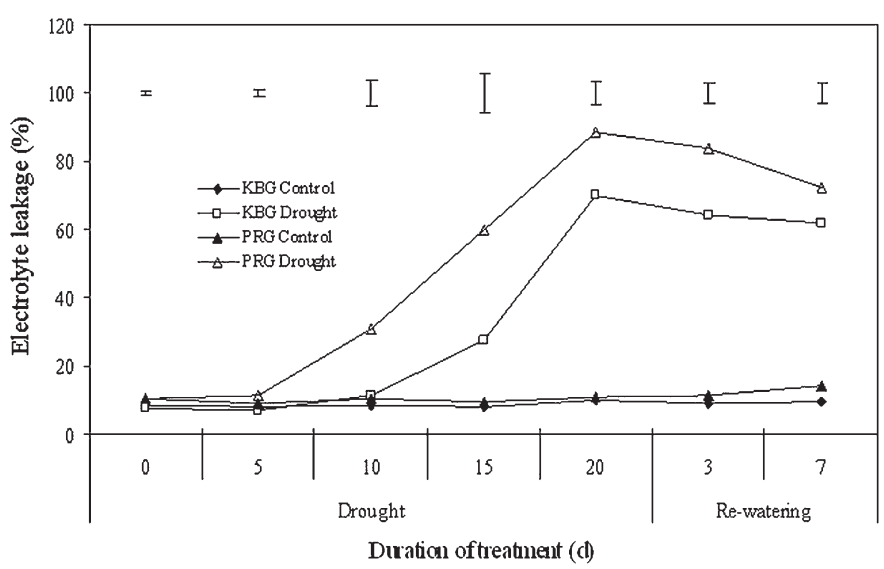

Fig. 3. Changes in cell membrane stability, as indicated by electrolyte leakage for kentucky bluegrass (KBG) and perennial ryegrass (PRG) leaves under drought stress and re-watering treatment. Vertical bars on the top indicate LSD values $(P \leq 0.05)$ for species and treatments comparison at the given day of treatment.

could not recover, even after re-watering. Similar results have been observed in two KBG cultivars in a previous study (Wang and Huang, 2004). However, KBG leaves were able to maintain better cell membrane stability than PRG under such severe drought stress. This result is in agreement with the results reported in Ma and Wang (2001).

Leaf chlorophyll and associated photochemical reactions are important factors in determining photosynthetic capacity. Decline in leaf $\mathrm{Chl}$ content is associated with leaf senescence induced by drought stress in various plant species (Wise and Naylor, 1987). Increases in EL and loss of chlorophyll usually are attributed to membrane damage and the processes occurring during drought-induced leaf senescence (Liu and Huang, 2000; Simon, 1974). In this study, no significant difference was detected in Chl content after $20 \mathrm{~d}$ of drought stress for KBG compared with the well-watered control (Fig. 4). During the rewatering treatment, Chl for KBG decreased, which was $72.2 \%$ and $80.5 \%$ of the well-watered control at 3 and $7 \mathrm{~d}$, respectively. For PRG, Chl content decreased to $46.5 \%$ of the 
well-watered control at $20 \mathrm{~d}$ of drought, and was only $39.2 \%$ and $36.1 \%$ of the well-watered control after 3 and $7 \mathrm{~d}$ of rewatering, respectively. The decline in Chl content or partial recovery in $\mathrm{Chl}$ content after re-watering in both grass species suggests that severe drought may have caused irreversible damage in leaf tissue, negating a recovery of Chl biosynthesis. However, leaf Chl content in KBG was significantly higher than that in PRG during drought and re-watering, which was $71.5 \%$, $59.0 \%$, and $68.0 \%$ higher at $20 \mathrm{~d}$ of drought stress, 3 and $7 \mathrm{~d}$ of re-watering, respectively. Leaf $\mathrm{Fv} / \mathrm{Fm}$ of $\mathrm{KBG}$ decreased to $22.9 \%$ of the well-watered control by $20 \mathrm{~d}$ of drought stress, and then increased to $80.3 \%$ and $96.3 \%$ of the well-watered control at 3 and $7 \mathrm{~d}$ of re-watering, respectively (Fig. 5). For PRG, Fv/ Fm decreased to only $8.9 \%$ of the control level after $20 \mathrm{~d}$ of drought stress, and increased to $39.6 \%$ and $83.5 \%$ of the wellwatered control at 3 and $7 \mathrm{~d}$ of re-watering, respectively. Leaf $\mathrm{Fv} / \mathrm{Fm}$ in PRG was $61.5 \%, 51.5 \%$, and $13.1 \%$ lower than that in $\mathrm{KBG}$ at $20 \mathrm{~d}$ of drought stress, 3 and $7 \mathrm{~d}$ of re-watering,

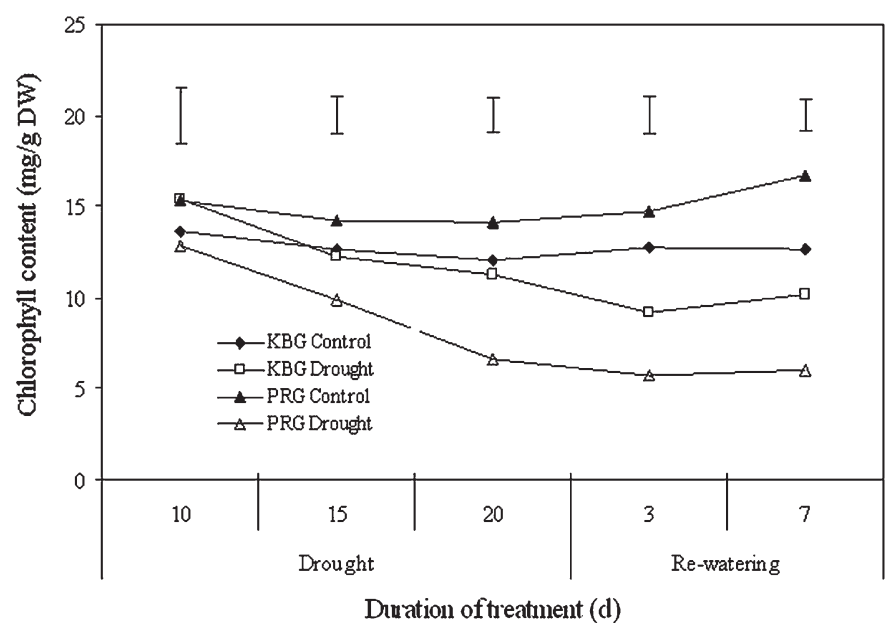

Fig. 4. Changes in chlorophyll content for kentucky bluegrass (KBG) and perennial ryegrass $(\mathrm{PRG})$ under drought stress and re-watering treatment. Vertical bars on the top indicate LSD values $(P \leq 0.05)$ for species and treatments comparison at the given day of treatment.

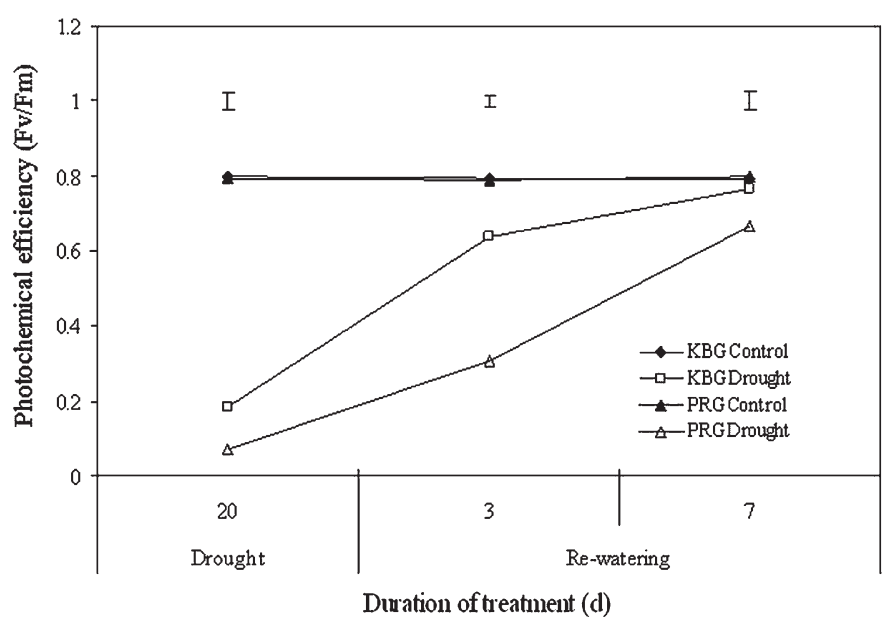

Fig. 5. Changes in photochemical efficiency (Fv/Fm) for kentucky bluegrass (KBG) and perennial ryegrass (PRG) under drought stress and re-watering. Vertical bars on the top indicate LSD values $(P \leq 0.05)$ for species and treatments comparison at the given day of treatment. respectively. The changes in $\mathrm{Chl}$ and $\mathrm{Fv} / \mathrm{Fm}$ ratio indicated that drought stress for $20 \mathrm{~d}$ induced severe leaf senescence, but KBG leaves were able to maintain greener and more active photochemical reactions than PRG leaves.

The level of TNC of a plant has been considered an indirect indicator of physiological activity and is related to the recuperative potential of plants from stress damages (Busso et al., 1990; Sheffer et al., 1979). TNC content in leaves of PRG did not exhibit significant changes during drought and re-watering compared with the control (Fig. 6A), while crown TNC content decreased by $30.8 \%$ at $20 \mathrm{~d}$ of drought stress and $18.3 \%$ at $7 \mathrm{~d}$ of re-watering (Fig. 6B). These results suggest that carbohydrate accumulation in leaves was unaffected by drought stress, but storage in crowns was inhibited during drought, which may affect the recuperative potential of plants from drought damage. Previous studies have also shown a reduction in concentrations of fructans and other water soluble carbohydrates in the basal stem and crown tissues in PRG and tall fescue (Festuca arundinacea) in response to drought stress (Norris and Thomas, 1982; Spollen and Nelson, 1994; Suzuki and Chatterton, 1993; Volaire and Gandoin, 1996). In contrast, TNC content in leaves of KBG increased by $35.1 \%$ at $20 \mathrm{~d}$ drought stress and $4.8 \%$ at $7 \mathrm{~d}$ of re-water treatment compared with the well-watered control (Fig. 6A). In KBG rhizomes, TNC content increased by $3.8 \%$ at $20 \mathrm{~d}$ of drought stress and decreased by $45.8 \%$ at $7 \mathrm{~d}$ of re-watering compared with the control (Fig. 6B). The accumulation of TNC in leaves and rhizomes in KBG during drought stress could serve as a carbohydrate reserve and/or used in osmotic adjustment, while the decrease in TNC content in rhizomes during re-watering may reflect the use or remobilization of carbohydrate from rhizomes for tissue re-growth.

Changes IN LEAF WATER RELATIONS AND CELL WALl MOdULUS DURING DROUGHT AND REWATERING. Leaf RWC for KBG decreased to $26.1 \%$ of the well-watered control by $20 \mathrm{~d}$ of drought (Fig. 7). By $7 \mathrm{~d}$ of re-watering, RWC for $\mathrm{KBG}$ increased to $45.0 \%$ of the well-watered control. Leaf RWC for PRG decreased to $25.7 \%$ of the well-watered control at $20 \mathrm{~d}$ of drought stress, and then increased to $40.8 \%$ of the well-watered control at $7 \mathrm{~d}$ of re-watering. No significant difference in RWC was found between the two species during drought stress or rewatering. These results indicated that leaves of both species suffered the same level of internal water deficit. Leaves of both species experienced severe water deficit (with RWC, as low as $24 \%$ ), which could not fully recover even after re-watering. A previous study with KBG found that RWC could not resume fully after $6 \mathrm{~d}$ of rewatering when RWC declined below 25\% during drought stress; a RWC of $25 \%$ was the critical level for whole-plant survival of drought stress for KBG (Wang and Huang, 2004). Prolonged, severe soil drying can ultimately cause cellular disruption to the point that leaves may no longer be fully rehydrated (Volaire et al., 1998a, 1998b). The critical RWC below which tissue physiological injuries and death occurs is $\approx 50 \%$, but can vary among species and tissue types (Taiz and Zeiger, 1998).

Osmotic adjustment is an important mechanism of dehydration tolerance, helping to maintain cell turgor and volume during drought stress (Clifford et al., 1998). Differences in $\psi_{\mathrm{S}}$ at $\psi_{\pi 100}$ are associated with species variation in drought tolerance and duration of water deficit (Barker et al., 1993). Osmotic potential at $\psi_{\pi 100}$ decreased by $17.3 \%$ in KBG after $15 \mathrm{~d}$ of drought stress compared with the well-watered control, while it did not change significantly in PRG (Table 1). 


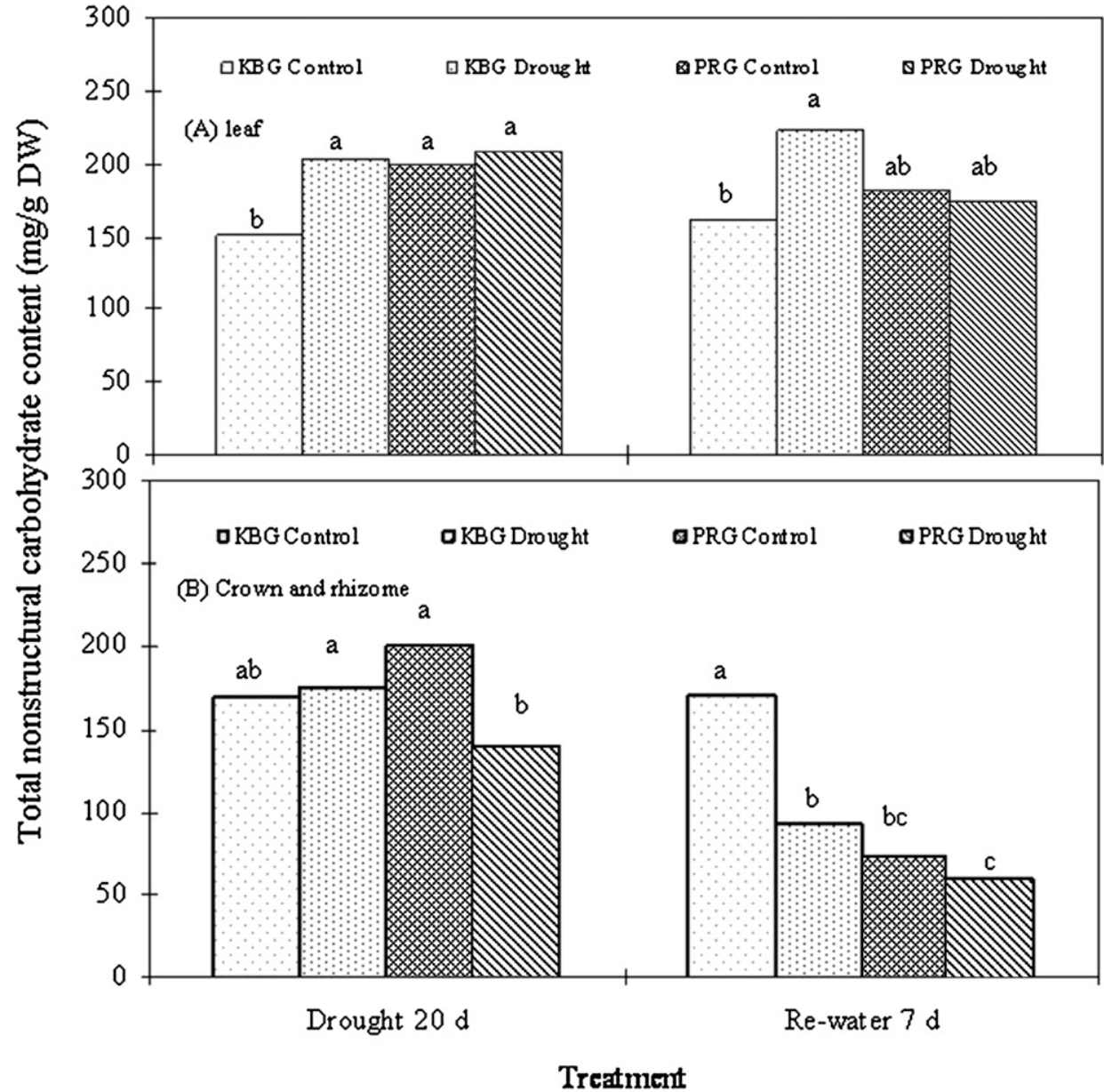

Fig. 6. Total nonstructural carbohydrate content (TNC) in leaves (A) and crown or rhizomes (B) in kentucky bluegrass (KBG) and perennial ryegrass (PRG) at $20 \mathrm{~d}$ of drought stress and $7 \mathrm{~d}$ of re-watering treatment. Means followed by the same letters within each treatment were not significantly different based on LSD test $(P \leq 0.05)$. creases in $\psi_{\pi 100}$ in PRG leaves could be due to the inhibition of osmotic solute accumulation or the lack of osmotic adjustment in this species under drought stress.

Cell wall elasticity is another important factor regulating cellular turgor and cell growth (Blake et al., 1991; Saito and Terashima, 2004). It is known that some plant species with elastic cell walls have a high inherent drought tolerance (Fan et al., 1994; Zimmermann and Steudle, 1978). Cell wall elasticity is negatively correlated to $\varepsilon$, which is often used to estimate cell wall elasticity. Leaf $\varepsilon$ values increased by $81.5 \%$ in PRG under drought stress compared with the well-watered control, while no significant difference in $\varepsilon$ was detected in KBG between the control and drought treatment (Table 1). PRG leaves had higher $\varepsilon$ values than KBG leaves under drought stress. The increase in $\varepsilon$ indicated that the cell wall in PRG leaves was less elastic than KBG leaves, thereby restricting cell growth in PRG leaves more than in KBG. The unchanged $\varepsilon$ in $\mathrm{KBG}$ leaves under drought stress suggested that these leaves could be able to maintain cell wall elasticity for turgor maintenance under drought stress. In fact, RWC at zero turgor of KBG was significantly lower than that of PRG, particularly under drought

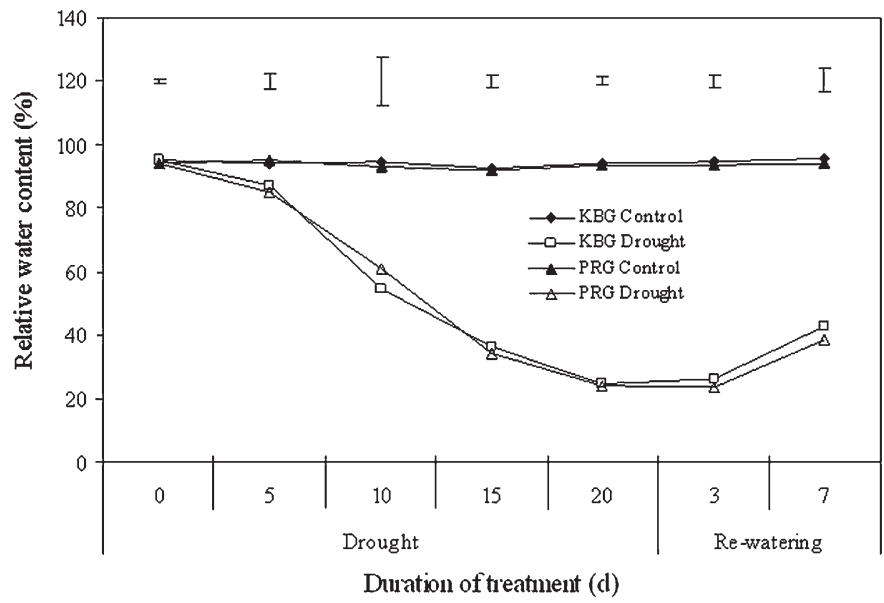

Fig. 7. Changes in relative water content (RWC) of kentucky bluegrass (KBG) and perennial ryegrass (PRG) under drought stress and re-watering treatment. Vertical bars on the top indicate LSD values $(P \leq 0.05)$ for species and treatments comparison at the given day of treatment.

Decreases in $\psi_{\pi 100}$ are associated with the increase in osmotic adjustment (Grammatikopoulos, 1999). The increases in osmotic adjustment during drought in KBG leaves could help maintain cellular turgor and physiological activities. The de- stress (Table 1), suggesting that KBG leaves were able to maintain turgidity with lower water content than PRG leaves. Cell turgor maintenance may be due to osmotic adjustment through active accumulation of solutes and/or an increase in solute concentration through reduced cell volume (elastic adjustment) (Grammatikopoulos, 1999). The increases in osmotic adjustment coupled with the maintenance of cell wall elasticity could help maintain growth during drought and facilitate growth during recovery from drought stress upon rewatering (Clifford et al., 1998).

The increases in leaf $\varepsilon$ values in PRG leaves were accompanied by decreases in TW/DW ratio. The TD/DW ratio indicates the water absorbing ability of a cell wall or a cell wall hydration level (Malinowski and Belesky, 2000). The TW/DW ratio in PRG leaves decreased by $18.8 \%$ during drought stress compared with the well-watered control. Decreases in TW/DW ratio have been observed in different genotypes of zoysiagrass (Zoysia japonica) exposed to drought stress compared with the pre-stress values (White et al., 2001). Such changes in cell wall properties could be associated with changes in cell wall thickness or cell wall constituents, as reported in tropical forage grass species (Wilson et al., 1980). No significant differences in TW/DW ratio for KBG were detected between the control and drought treatment. The lack of changes in TW/DW suggested that KBG leaves were better able to maintain cell wall 
hydration level under drought stress compared with PRG leaves (Malinowski and Belesky, 2000).

CoRrelation aNALYSIS OF PHYSIOLOGICAL FaCtORS UNDER DROUGHT. Correlation analysis was performed between grass quality as an overall drought performance indicator and EL, which is commonly used as an indicator for cellular damage under drought (DaCosta and Huang, 2006). Correlation between parameters estimated from the pressure-volume curve and EL for leaves of both species exposed to drought stress was also analyzed. For both grass species, EL was negatively correlated with grass quality $\left(\mathrm{r}^{2}=0.92\right.$ for KBG, $\mathrm{r}^{2}=0.97$ for PRG). The $\psi \pi_{100}$ has been shown to be correlated to drought tolerance and suggested as a rapid and economical selection tool for drought tolerance (White et al., 2001). In this study, $\Psi_{\pi 100}$ was negatively correlated with EL $\left(r^{2}=0.80\right)$ or positively correlated with cell membrane stability under drought stress in KBG, but the correlation was not significant in PRG leaves $\left(\mathrm{r}^{2}=0.37\right)$. These results indicated that osmotic adjustment may be involved in protection of cellular membranes from drought damage or, in turn, stable cellular membranes may facilitate solute accumulation or prevent electrolyte leakage from leaves exposed to drought stress in KBG. In contrast, $\mathrm{RWC}_{0}$ was negatively correlated to cell membrane stability and positively correlated to EL in both $\operatorname{KBG}\left(r^{2}=0.83\right)$ and PRG $\left(r^{2}=0.66\right)$, suggesting that leaves with stable cell membranes could lose turgor at a lower RWC or maintain turgid with lower water availability.

Leaf $\varepsilon$ was positively correlated with EL in $\mathrm{KBG}\left(\mathrm{r}^{2}=0.74\right)$ and PRG $\left(\mathrm{r}^{2}=0.99\right)$. The negative correlation between $\varepsilon$ and cell membrane stability in both grass species suggested elastic cell walls accompanied by stable membranes may play an important role in leaf dehydration tolerance as the coupled changes may prevent plasma membrane separation from cell walls or plasmolysis, which is critical for the maintenance of cell turgor and cell growth (Nilsen and Orcutt, 1996).

RE-GREENING AND REHYDRATION OF DROUGHT-DAMAGED LEAVES AND REGENERATION OF NEW ROOTS IN RESPONSE TO REWATERING. Leaf senescence during drought stress may conserve water by decreasing transpirational leaf area, but the attribute of regreening and rehydration of senescent, desiccated leaves may play a critical role in the resumption of plant growth when water becomes available (Munne-Bosch and Alegre, 2004). At 3 and $7 \mathrm{~d}$ of re-watering, rehydrated, green leaf percentages of drought-damaged leaves in terms of number, area, and length of leaves (rehydrated leaves in proportion to all leaves) were all significantly higher in KBG compared with those in PRG (Fig. $8)$. These data indicated that desiccated, senescent leaves in KBG induced by drought stress were better able to re-green and be rehydrated upon re-watering compared with PRG leaves, which may also reflect less physiological or cellular damages in KBG leaves under drought stress.
At $7 \mathrm{~d}$ of re-watering treatment, new roots were found in KBG and PRG plants. The new roots in PRG were 1.33 times greater in total surface area, 1.27 times higher in total length, and 1.35 times more in total dry weight than KBG roots; the number of new roots, however, were significantly lower than in KBG (Fig. 9). At $16 \mathrm{~d}$ of re-watering, new roots for PRG were $25.8 \%$ higher in total length, $85.5 \%$ higher in total surface area, 1.66 times higher in total dry weight, but root number was $15.9 \%$ lower compared with those in KBG. These data demonstrate that PRG exhibited more rapid elongation of new roots while KBG was able to regenerate a greater number of new roots in response to re-watering.

The survival rate of plants from drought stress, expressed as percentage of the number of new tillers produced after rewatering to the total number of tillers, was also evaluated at $16 \mathrm{~d}$ of re-watering. A significant amount of new tillers were regenerated in both species in response to re-watering even though plants were exposed to prolonged periods $(20 \mathrm{~d})$ and severe drought stress $(\mathrm{SWC}=4 \%, \mathrm{RWC}=24 \%)$. The survival rate for KBG $(90.6 \%)$ was significantly higher than that for PRG (82.3\%). These results indicated that both perennial grass species had high survivability, but KBG was better than PRG. The differential responses of root growth and tiller production between the two species suggested that new root formation

Table 1. Osmotic potential at full turgor $\left(\psi_{\pi 100}\right)$, relative water content at zero turgor $\left(\mathrm{RWC}_{0}\right)$, bulk modulus of tissues elasticity $(\varepsilon)$, and the ratio of turgid weight to dry weight (TW/DW) determined under well-watered control and drought stress at $15 \mathrm{~d}$ of treatment for kentucky bluegrass (KBG) and perennial ryegrass (PRG).

\begin{tabular}{llcccc}
\hline & & $\psi_{\pi 100}(\mathrm{MPa})$ & $\mathrm{RWC}_{0}(\%)$ & $\varepsilon(\mathrm{MPa})$ & $\mathrm{TW} / \mathrm{DW}$ (ratio) \\
\hline KBG & Control & $-1.44 \mathrm{ab}^{\mathrm{z}}$ & $88.44 \mathrm{~b}$ & $-0.63 \mathrm{~b}$ & $4.11 \mathrm{c}$ \\
& Drought & $-1.69 \mathrm{a}$ & $89.55 \mathrm{~b}$ & $-0.64 \mathrm{~b}$ & $4.08 \mathrm{c}$ \\
PRG & Control & $-1.35 \mathrm{~b}$ & $91.03 \mathrm{ab}$ & $-0.54 \mathrm{c}$ & $5.28 \mathrm{a}$ \\
& Drought & $-1.24 \mathrm{~b}$ & $93.01 \mathrm{a}$ & $-0.98 \mathrm{a}$ & $4.29 \mathrm{~b}$ \\
\hline
\end{tabular}

${ }^{\mathrm{z}}$ Means followed with the same letters within the column were not significantly different at $P \leq 0.05$ level based on LSD test.

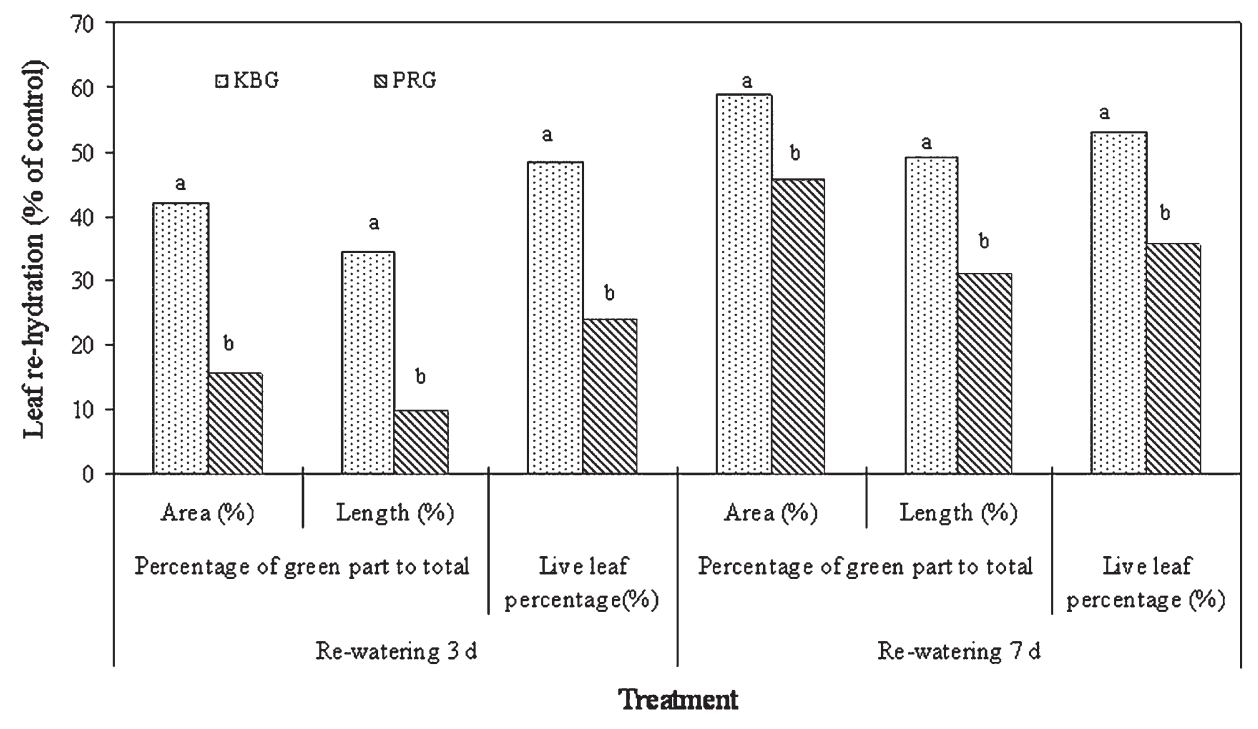

Fig. 8. Percentage of green part to total leaf area and length, and live leaf percentage of existing leaves of kentucky bluegrass (KBG) and perennial ryegrass (PRG) under re-watering treatment. Means followed by the same letters for each parameter were not significantly different based on LSD test $(P \leq 0.05)$. 

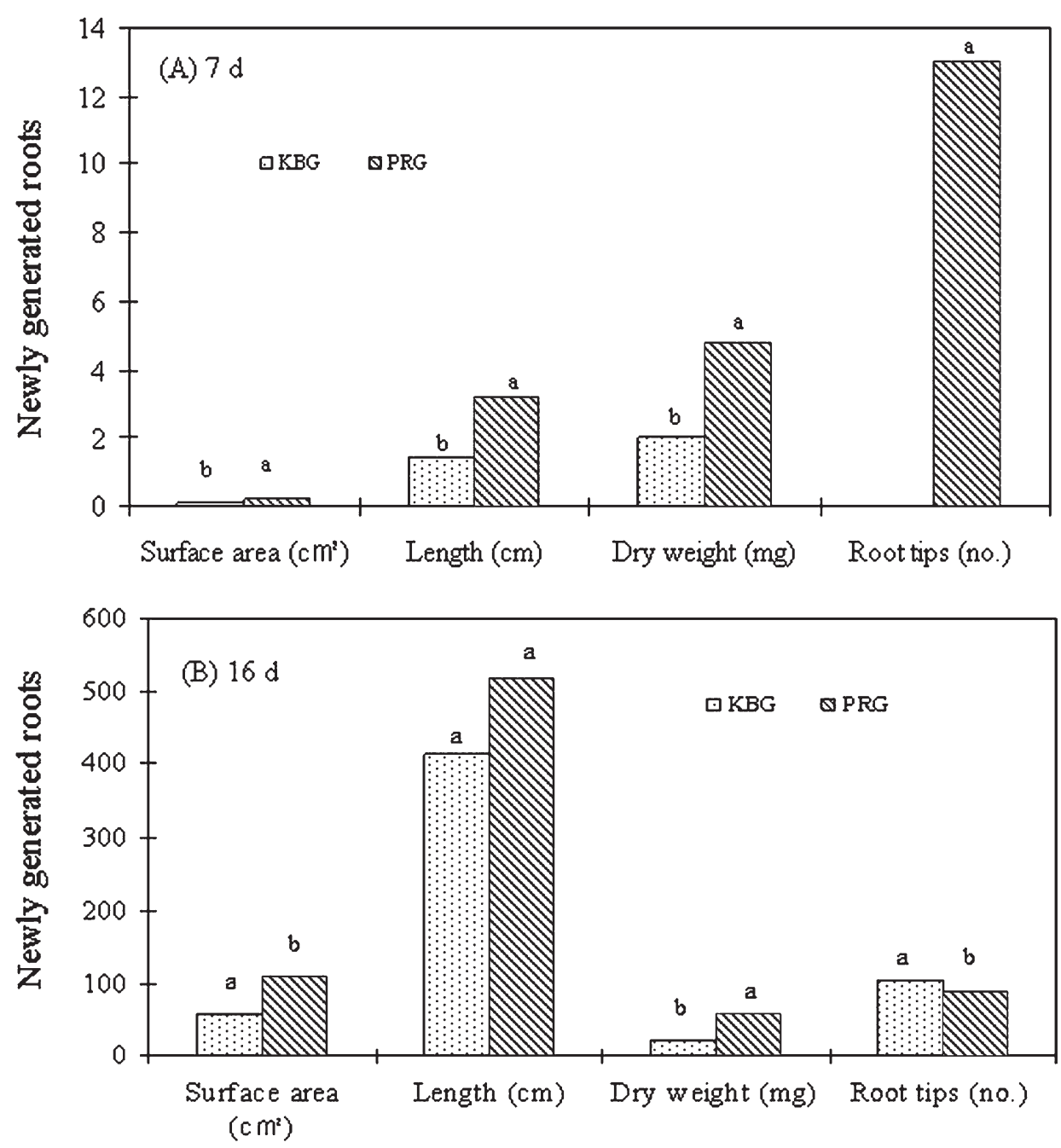

Fig. 9. Area, length, dry weight, and numbers of newly regenerated roots at 7 and $16 \mathrm{~d}$ of re-watering in kentucky bluegrass (KBG) and perennial ryegrass (PRG). Means followed by the same letters for each parameter were not significantly different based on LSD test $(P \leq 0.05)$.

could be more critical, relative to root elongation, for leaf rehydration or regeneration of new tillers upon re-watering.

\section{Summary}

Kentucky bluegrass exhibited superior drought survival and recuperative potential than $\mathrm{PRG}$, as manifested by the maintenance of higher grass quality, leaf $\mathrm{Chl}$, and $\mathrm{Fv} / \mathrm{Fm}$ under the same level of water deficit during drought stress and more rapid and greater extent of recovery in all these physiological parameters upon re-watering. Osmotic adjustment, cell wall elasticity, and cell membrane stability were closely correlated to leaf desiccation tolerance or drought survival in perennial grass species. Post-drought recovery in leaf hydration level and physiological activities could be associated with the accumulation of carbohydrates in leaves and rhizomes during drought stress and new root production after re-watering.

\section{Literature Cited}

Barker, D.J., C.Y. Sullivan, and L.E. Moser. 1993. Water deficit effects on osmotic potential, cell wall elasticity, and proline in five forage grasses. Agron. J. 85:270-275.
Barrs, H.D. and P.E. Weatherley. 1962. A re-examination of the relative turgidity techniques for estimating water deficits in leaves. Aust. J. Biol. Sci. 15:413-428.

Beard, J.B. 1973. Turfgrass science and culture. Prentice Hall, Englewood Cliffs, NJ.

Blake, T.J., E. Bevilacqua, and J.J. Zwiazek. 1991. Effects of repeated stress on turgor pressure and cell elasticity changes in black spruce seedlings. Can. J. For. Res. 21:1329-1333.

Busso, C.A., J.H. Richards, and N.J. Chatterton. 1990. Nonstructural carbohydrates and spring re-growth of two cool-season grasses: Interaction of drought and clipping. J. Range Manage. 43:336-343.

Carrow, R.N. 1996. Drought resistance aspects of turfgrasses in the Southeast: Root-shoot responses. Crop Sci. 36:687-694.

Clifford, S.C., S.K. Arndt, J.E. Corrlett, S. Joshi, N. Sankhla, M. Popp, and H.G. Jones. 1998. The role of solute accumulation, osmotic adjustment and changes in cell wall elasticity in drought tolerance in Zizipphus mauritiana (Lamk.). J. Expt. Bot. 49:967-977.

DaCosta, M. and B. Huang. 2006. Deficit irrigation effects on water use characteristics of bentgrass species. Crop Sci. 46:1779-1786.

DaCosta, M., Z. Wang, and B. Huang. 2004. Physiological adaptation of kentucky bluegrass to localized soil drying. Crop Sci. 44:1307-1314.

Ensign, R.D. and G.C. Weiser. 1975. Root and rhizome development of some kentucky bluegrass and red rescue cultivars. Agron. J. 67:583-585.

Fan, S., T.J. Blake, and E. Blumwald. 1994. The relative contribution of elastic and osmotic adjustments to turgor maintenance in woody species. Physiol. Plant. 90:408-413.

Fry, J. and B. Huang. 2004. Applied turfgrass science and physiology. Wiley. Hoboken, NJ.

Grammatikopoulos, G. 1999. Mechanisms for drought tolerance in two Mediterranean seasonal dimorphic shrubs. Aust. J. Plant Physiol. 26: 587-593.

Hardebeck, G. and C. Bigelow. 2008. National perennial ryegrass 2000 test. Natl. Turfgrass Evaluation Prog. Rpt. 9-11.

Hiscox, J.D. and G.F. Israeltem. 1979. A method for extraction of chlorophyll from leaf tissue without maceration using dimethyl sulfoxide. Can. J. Bot. 57:1332-1334.

Jiang, Y. and B. Huang. 2001. Effects of calcium on antioxidant activities and water relations associated with heat tolerance in two cool-season grasses. J. Expt. Bot. 52:341-349.

Kanapeckas, J., N. Lemeziene, V. Stukonis, and P. Tarakanovas. 2008. Drought tolerance of turfgrass genetic resources. Biologja 54:121-124.

Kirkham, M.B. 2005. Principles of soil and plant water relations. Elsevier Academic Press, Burlington, MA.

Li, G.M., L.S. Tsng, Z.Q. Shang, and S.M. Chi. 1994. Effect of osmotic stress on protectice enzyme systems in maize seedling and their relationship to drought resistance. J. Hebei Agr. Univ. 17:1-5.

Li, J.X., J.F. Yun, B.D. Su, R. Wu, and R. Yi. 2004. Study on the drought resistance comparison of 6 populations of Agropyron 
cristatum in the germination period and seedling stage. J. Arid Land Res. Environ. 18:163-167.

Liu, X. and B. Huang. 2000. Heat stress injury in relation to membrane lipid peroxidation in creeping bentgrass. Crop Sci. 40:503-510.

Lu, J.Y. and J.F. Gao. 1996. Effects of water stress on plasma membrane permeability and compositions in wheat roots. Agr. Res. Arid Areas 14:96-100.

Ma, Y. and C. Wang. 2001. Growth and physiological indices for drought resistance on introduced cold-season turfgrass. Pratacultural Sci. 18:57-61.

Malinowski, D.P. and D.P. Belesky. 2000. Adaptations of endophyteinfected cool-season grasses to environmental stresses: Mechanisms of drought and mineral stress tolerance. Crop Sci. 40:923-940.

Martin, V., S.G. Pakllardy, and Z.A. Bahari. 1987. Dehydration tolerance of leaf tissue of six woody angiosperm species. Physiol. Plant. 669:182-186.

Munne-Bosch, S. and L. Alegre. 2004. Die and let live: Leaf senescence contributes to plant survival under drought stress. Funct. Plant Biol. 31:203-216.

Nelson, N. 1944. A photometric adaptation of the Somogyi method for the determination of glucose. J. Biol. Chem. 153:375-380.

Nilsen, E.T. and D.M. Orcutt. 1996. Water limitation, p. 322-361. In: E.T. Nilsen and D.M. Orcutt (eds.). Physiology of plants under stress: Abiotic factors. Wiley, New York.

Norris, J.B. and H. Thomas. 1982. The effect of cutting on regrowth of perennial ryegrass selections exposed to drought conditions. Wales J. Agr. Sci. 99:547-553.

Saito, T. and I. Terashima. 2004. Reversible decreases in the bulk elastic modulus of mature leaves of deciduous Quercus species subjected to two drought treatments. Plant Cell Environ. 27:863875.

Schulte, P.J. and T.M. Hinckley. 1985. A comparison of pressurevolume curve data analysis techniques. J. Expt. Bot. 36:1590-1602. Sheffer, K.M., T.L. Watschke, and J.M. Duich. 1979. Carbohydrate sampling in kentucky bluegrass turfgrass. Agron. J. 71:301-304.

Shinozaki, K. and K. Yamaguchi-Shinozaki. 1997. Gene expression and signal transduction in water stress response. Plant Physiol. 115:327-334.

Simon, E.W. 1974. Phospholipids and plant membrane permeability. New Phytol. 73:377-420.

Siopongco, J.D., A. Yamauchi, H. Salekdeh, J. Bennett, and L.J. Wade. 2006. Growth and water use response of doubled-haploid rice lines to drought and rewatering during the vegetative stage. Plant Prod. Sci. 9:141-151.

Somogyi, N.A. 1945. A new reagent for the determination of sugar. J. Biol. Chem. 160:61-68.

Spollen, W.G. and C.J. Nelson. 1994. Response of fructan to water deficit in growing leaves of tall fescue. Plant Physiol. 24:706-719.

$\mathrm{Su}$, K., D.J. Bremer, S.J. Keeley, and J.D. Fry. 2008. Rooting characteristics and canopy responses to drought of turfgrasses including hybrid bluegrasses. Agron. J. 100:949-956.
Sun, J. 2008. Turfgrass science. 3rd ed. China Agriculture Press, Beijing, China.

Sun, Y., Q.C. Yang, and Y.H. Zhang. 2001. Studies on drought tolerance of eight turfgrass cultivars at seedling stage. Acta Agrestia Sinica 9:16-20.

Suzuki, M. and N.J. Chatterton. 1993. Fructans in crop production and preservation. The science and technology of fructans. CRC Press, Boca Raton, FL.

Taiz, L. and E. Zeiger. 1998. Plant Physiology. 1st Ed. Sinauer Associates Inc., Massachusetts, London.

Touchette, B.W. 2006. Salt tolerance in a Juncus roemerianus brackish marsh: Spatial variations in plant water relations. J. Exp. Mar. Biol. Ecol. 337:1-12.

Turgeon, A.L. 1996. Turfgrass management. Prentice Hall, Englewood Cliffs, NJ.

Volaire, F. and J.M. Gandoin. 1996. The effect of age of the sward on the relationship between water-soluble carbohydrate accumulation and drought survival in two contrasted populations of cocksfoot (Dactylis glomerata L.). Grass Forage Sci. 51:190-198.

Volaire, F. and F. Lelievre. 2001. Drought survival in Dactylis glomerata and Festuca arundinacea under similar rooting conditions in tubes. Plant and Soil 229:225-234.

Volaire, F., H. Thomas, and F. Lelièvre. 1998a. Survival and recovery of perennial forage grasses under prolonged Mediterranean drought. I. Growth, death, water relations and solute content in herbage and stubble. New Phytol. 140:439-449.

Volaire, F., H. Thomas, N. Bertagne, E. Bourgeois, M.F. Gautier, and F. Lelièvre. 1998b. Survival and recovery of perennial forage grasses under prolonged Mediterranean drought. II. Water status, solute accumulations, abscisic acid concentration and accumulation of dehydrin transcripts in bases of immature leaves. New Phytol. 140:451-460.

Wang, Z. and B. Huang. 2004. Physiological recovery of kentucky bluegrass from simultaneous drought and heat stress. Crop Sci. 44:1729-1736.

White, R.H., M.C. Engelke, S.J. Morton, and B.A. Ruemmele. 1992. Competitive turgor maintenance in tall fescue. Crop Sci. 32:251-256.

White, R.H., M.C. Engelke, S.J. Anderson, B.A. Ruemmele, K.B. Marcum, and G.R. Taylor, II. 2001. Zoysiagrass water relations. Crop Sci. 41:133-138.

Wilson, J.R., M.J. Fisher, E.D. Schulze, G.R. Dolby, and M.M. Ludlow. 1979. comparison between pressure-volume and dewpoint-hygroetry techniques for determining the water relations characteristics of grass and legume leaves. Oecologia 41:77-88.

Wilson, J.R., M.M. Ludlow, M.J. Fisher, and E.D. Schulze. 1980. Adaptation to water stress of the leaf water relations of four tropical forage species. Aust. J. Plant Physiol. 7:207-220.

Wise, R.R. and A.W. Naylor. 1987. Chilling-enhanced photo-oxidation. The peroxidative destruction of lipids during chilling injury to photosynthesis and ultrastructure. Plant Physiol. 83:278-282.

Zimmermann, U. and E. Steudle. 1978. Physical aspects of water relations of plant cells. Adv. Bot. Res. 6:45-117. 